\title{
Ground Water Conditions and Spatial Distribution of Lead and Cadmium in the Shallow Aquifer at Effurun- Warri Metropolis, Nigeria
}

\author{
Irwin A. Akpoborie ${ }^{1}$, Alex E. Uriri ${ }^{2} \&$ Oghenevwede Efobo ${ }^{3}$ \\ ${ }^{1}$ Department of Geology, Delta State University, Abraka, Nigeria \\ ${ }^{2}$ Department of Geography and Planning, University of Lagos, Lagos, Nigeria \\ ${ }^{3}$ Center for Research in Water and Environment, Abraka, Nigeria \\ Correspondence: Irwin A. Akpoborie, Department of Geology, Delta State University, Abraka, Nigeria. E-mail: \\ tony.akpoborie@gmail.com
}

Received: April 22, 2014 Accepted: May 15, 2014 Online Published: June 28, 2014

doi:10.5539/ep.v3n3p27 URL: http://dx.doi.org/10.5539/ep.v3n3p27

\begin{abstract}
A water table head distribution map of the shallow Benin Formation aquifer in the Effurun-Warri area has been drawn from dug well data and used to define groundwater gradients as well as identify directions of groundwater movement in this densely populated urban setting. Water samples from forty dug wells were also screened for the presence of lead and cadmium and results showed a variation in concentration from not detectable to $0.04 \mathrm{mg} / \mathrm{l}$ for each metal. Iso-concentration contours for lead in groundwater suggest that enrichment may be from two sources: wastes from the refinery and petrochemical industrial complex on the northwestern edge of the city and secondly from leachates associated with the many unregulated waste dumpsites. Lead appears to be constrained from spreading eastwards from the industrial complex area by the south and westwards trending groundwater gradient. The city wide prevalence of elevated levels of cadmium is also probably due to leachates from unregulated dumpsites as well as the mixing of groundwater as suggested by existing gradients. Potential implications of the findings for public health, local and regional water quality monitoring are discussed.
\end{abstract}

Keywords: heavy metals, lead, cadmium, groundwater, urban water, leachates, Niger Delta, Benin Formation

\section{Introduction}

Lead and cadmium have been identified as two of several heavy metals that can impair human organ function when ingested even in minute quantities. Sarojam (2011) notes for example, that heavy metals in general are known to cause harmful reproductive effects and draws attention to the non degradability of lead and calcium in nature and hence their tendency to accumulate in the food chain. Ifegwu and Ayankora (2012), WHO (2011, 2010), the American College of Obstetricians and Gynecologists (AMCOG, 2012) provide summary descriptions of the mechanisms through which organ and enzyme dysfunction are associated with their ingestion. Specifically, excessive intake of lead has been associated with multiple problems including cancer, intestinal nephritis, hypospermia, testicular atrophy, learning disorders and in large quantities, death. Indeed, the United States Agency for Toxic Substances and Disease Registry (ATSDR, 2007) states that while the developing nervous system, cardiovascular systems, and the kidney are the most sensitive targets for lead toxicity, lead could potentially affect any system or organs in the body. Cadmium is also toxic to kidneys when ingested in excess.

Several studies including Aremu, Olawuyi, Metshitsuka, Sridhar, \& Oluwande (2002), Otobo, Aigbogun, and Ifedili (2007); Akodu, Ozulu and Osagbue (2010); Basorun and Olamiju (2013) Ogbeibu, Chukwurah and Oboh, (2013), Iwegbue, Nwajei, Ogala and Overah (2010) have shown the presence of elevated levels of heavy metals including lead and cadmium in soils, storm runoff and shallow ground water in the Effurun- Warri area. Etchie, Etchie and Adewuyi (2011) use principal component analysis to show that the presence of these heavy metals in parts of the city's groundwater are associated with nearby refinery operations while Abimbola, Oke and Olatunji (2004), Akodu, Ozulu and Osagbue (2010) and Ogbeibu, Chukwurah and Oboh, (2013) show that leachate from unregulated dumpsites in the city are point sources for heavy metal loading of the underlying aquifer. Additional non point sources of these contaminants possibly include open storm water drains that contain sediment with elevated levels of lead and cadmium of up to $1.4 \mathrm{mg} / \mathrm{kg}$ and $0.6 \mathrm{mg} / \mathrm{kg}$ respectively (Egboh, Nwajei \& Adaikpoh, 
2000) as well as nearby creeks and water courses in the area that are contaminated with industrial effluent (Emoyan, Akporhonor \& Akpoborie, 2008; Nduka \& Orisakwe, 2009). Unfortunately, a dysfunctional and inadequate public agency water supply system has driven residents, industry and commercial establishments in the Effurun-Warri metropolis to rely on groundwater from shallow dug wells and boreholes drilled into the upper horizon of the Benin Formation aquifer for self supplies. While the chemical quality of water from these sources meets regulatory agency standards for domestic use (Olobaniyi \& Owoyemi, 2004; Ejechie, Olobaniyi, Ogban \& Ugbe, 2007) the spatial distribution of reported lead and cadmium in the city's shallow groundwater is not well understood. Spatial distribution would be controlled largely by textural as well as lithological variations and by existing groundwater gradients in the aquifer that determine the direction of ground water flow and other mixing phenomena.

The objectives of this study which is part of a comprehensive hydro-geochemical evaluation of the shallow aquifer are twofold: first, to establish for the first time, geo-referenced groundwater gradients in the shallow aquifer; second, determine levels of occurrence of lead and cadmium in groundwater and identify the influence of existing gradients on the spatial distribution of these heavy metals in groundwater in this rapidly expanding urban setting. These are important issues in water supply planning and aquifer protection especially as they relate to the future design and location of solid and liquid waste management systems and public health.

\subsection{Area of Study}

The study area includes the Warri-Effurun metropolis and the adjoining rural fringes that lie roughly between latitude $5^{\circ} 30^{\prime} \mathrm{N}-5^{\circ} 45 \mathrm{~N}$ and longitude $5^{\circ} 15^{\prime} \mathrm{E}-5^{\circ} 50^{\prime} \mathrm{E}$, Figure 1, Figure 2 . The small and rural river port of Warri town with a population of a mere 20,000 people in 1933, has expanded to become the present day agglomeration of many towns and communities that include Effurun, Ekpan, Enerhen, Edjeba, Ogunu, Jakpa, Ovian-Aladja. These towns and communities are also the main population centers of four core local government areas (LGAs), namely: Uvwie, Warri South, Warri South West and Udu, Figure 1. The 1991 Nigerian census recorded the population of these LGAs that substantially make up the population of the Warri-Effurun metropolis at 450,362 ; this increased to 754,931 by the 2006 census and projected to have reached 852,317 by year 2010. Indeed, Babatola and Uriri (2013) projected a population of one million inhabitants by mid- year 2013 for this metropolis that is the hub of the oil and gas industry in the western Niger Delta petroleum province as well as the most populous industrial and commercial center of Delta state, Nigeria.

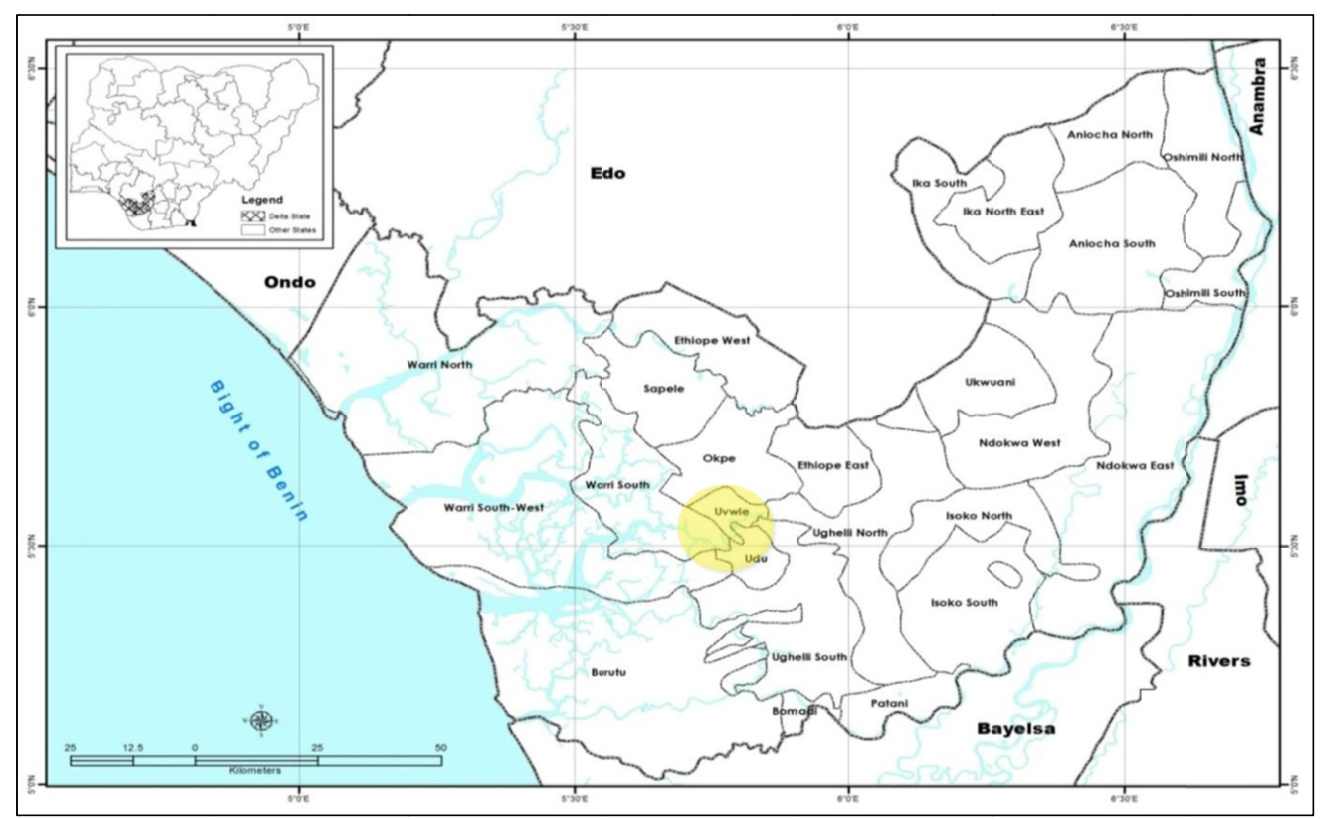

Figure 1. Map of Delta State showing LGA boundaries and the position of the Effurun-Warri Metropolis (marked in yellow) 


\subsection{Physiography and Climate}

The Effurun-Warri area is typical Sombreiro- Warri Deltaic Plain (SWDP) terrain which is monotonously lowland and flat with a gentle slope towards existing water courses and swamps. The western edge rests on the equally low lying and extensive wetland, the Brackish Water Mangrove Swamps (BMS) that stretches westwards to the Atlantic coast. The area is drained by the Warri River and its subordinate network of creeks. The swamps on the north bank of the Warri River have largely been reclaimed for urban development and only patches of mangrove vegetation remain on this as well as on the banks of the creeks at Edjeba, Bendel Estate, and Ogunu that flow into the Warri River, Figure 2.

The climate is equatorial, hot $\left(23^{\circ} \mathrm{C}-37^{\circ} \mathrm{C}\right)$ and humid (Relative Humidity, $50-70$ per cent). There is a dry season from about November to February, and a wet season that begins in March and peaks in July and October. Mean annual rainfall is 2,500 -3000mm (Adejuwon, 2012).

\subsection{Geology and Distribution of Quaternary Recent (Holocene) Deposits}

The geology of the Niger Delta petroleum province is much studied and descriptions may be found in Short and Stauble (1967) among many others. In summary, the Benin Formation is the youngest of the three important formations that constitute the sedimentary fill of the Niger Delta Basin. The formation consists of massive continental/fluvial sands and gravels. The older formations which are encountered only in the subsurface in the Warri area are the Agbada Formation of paralic sands and shales and the basal Akata Formation which consists of holomarine shales, silts and clays. Thus the Benin Formation underlies the Effurun-Warri area but is overlain and masked by deposits of the SDWP and BMS. These deposits are typically successions of fine to medium grained unconsolidated sands interbedded with thin discontinuous layers of clay in the SDWP and thin and dark grey silts and discontinuous clays in case of the BMS (Akpoborie, Ekakite \& Adaikpoh, 2000; Akpoborie \& Aweto, 2012).

\section{Methodology}

One hundred and twenty nine dug wells dug wells which are evenly distributed in the city were selected for water level monitoring in the wet season. Depth to water level in each of the dug wells were measured with a Solinst model electronic water level indicator. An Ertec model GPS instrument was used to determine coordinates and to locate the well positions on the city map. Because available city maps are devoid of contours as are all maps of this general Niger Delta region, averaged elevation readings from the altimeter module of three GPS instruments at each site were used to approximate the elevation of each well location. Results were employed in generating the depth to water level as well as the water table head distribution using Surfer 8 (Golden Software Inc., 2002).

Furthermore, approximately 40 dug wells located across the city were randomly selected for ground water sampling. Samples were collected from the selected dug wells and screened for the major ions as well as selected heavy metals. In the sampling procedure, replicate water samples were collected from each dug well into sterilized polyethylene bottles. The set of samples designated for heavy metal analysis were immediately stabilized in situ with nitric acid, stored in ice boxes and sent to the laboratory within an hour of collection for analysis. At the laboratory, the Pye Unicam Atomic Absorption Spectrophotometer SP 2900 was employed in the determination of levels of lead and cadmium.

\section{Results}

\subsection{Groundwater Conditions}

Data from about forty evenly spread dug well locations out of the one hundred and twenty points measured were selected and employed in constructing water table contour lines of equal head in meters above sea level as shown in Figure 2. The selected locations and associated data are presented in Table 1. Depth to water level in the shallow aquifer ranges from a minimum of $0.75 \mathrm{~m}$ at Ugboroke through $3 \mathrm{~m}$ at Effurun Market to a maximum of $5 \mathrm{~m}$ below ground level at the Airport Junction area. The configuration of the water table reveals the presence of a groundwater mound which is aligned in a northeast to southwest direction in the city and which begins at the Effurun GRA area and continues through Ugborikoko to Ajamimogha. This mound is also somewhat equidistant from the Ogunu Creek to the north and Warri River to the south. Groundwater moves from it southwards from the neighborhood of Okumagba Layout through Igbudu and Agbassa neighbourhoods to Warri River and northwards from Ugborikoko and Ugboroke to feed the Ogunu Creek. At Edjeba and Ajamimogha, movement from it is northwestwards and westwards to join the Ogunu Creek and Warri River respectively. In the vicinity of the NNPC refinery and petrochemical complex located at the northwest corner of the city, groundwater movement is northwest towards the reclaimed wetland area of Ubeji community and also west and southwards. 
In the eastern part of the city at Ekete, Oruwhorun and DSC Steel Town, movement is eastwards and away from the Warri River. Therefore, the Warri River and Ogunu Creek appear to have a major influence on groundwater movement in the city. Olobaniyi and Owoyemi's (2004) model has somewhat similar characteristics but has remarkable differences in the configuration of the water table.

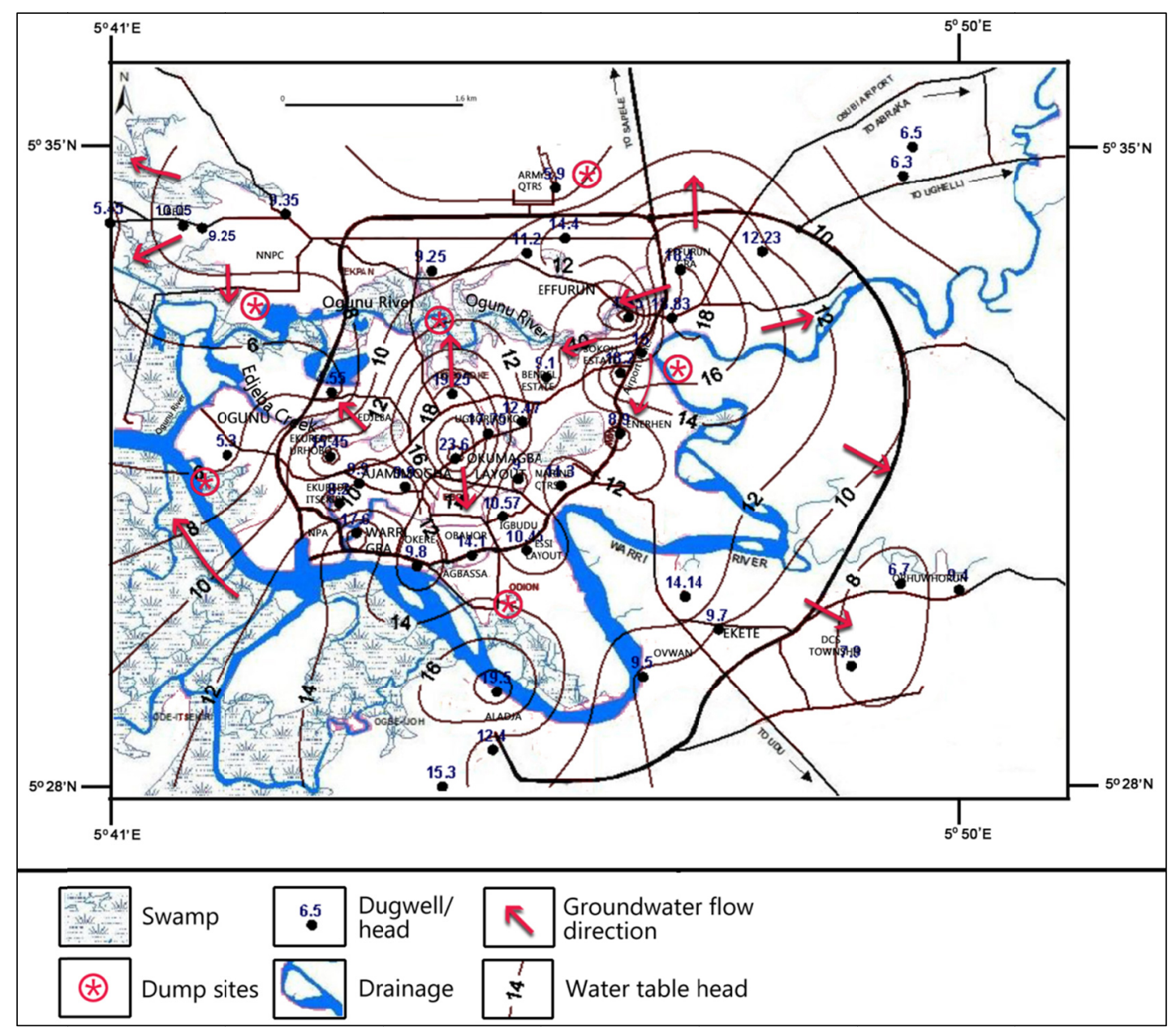

Figure 2. Effurun- Warri metropolis: water table contour lines of equal head in meters above sea level (Base map modified from Urhobo Historical Society, 2014) 
Table 1. Depth to water level (DWL) data and calculated head from dug wells in Effurun-Warri

\begin{tabular}{|c|c|c|c|c|}
\hline Easting & Northing & Location Name & DWL & Head \\
\hline 5.704667 & 5.57105 & Ubeji Health Centre & 1.95 & 10.05 \\
\hline 5.707861 & 5.570611 & Town Hall Ubeji & 1.75 & 9.25 \\
\hline 5.692333 & 5.571472 & Seko Est Ubeji Deeper Life Road, Ubeji & 1.55 & 5.45 \\
\hline 5.722167 & 5.573056 & Jeddo/Ubeji Junction & 2.65 & 9.35 \\
\hline 5.746944 & 5.563222 & Ekpan Secondary School & 2.75 & 9.25 \\
\hline 5.729972 & 5.542194 & Opposite Holy Family Catholic Church & 2.45 & 4.55 \\
\hline 5.729694 & 5.531167 & Off Okundolor Street Ekurede Urhobo & 1.55 & 15.45 \\
\hline 5.828472 & 5.58475 & 13, Omoteko Anikopi St. Okuokoko & 3.5 & 6.5 \\
\hline 5.826889 & 5.579694 & 1, James Ovie St. Okuokoko & 2.7 & 6.3 \\
\hline 5.789917 & 5.506889 & 17, Boro St. Owhasa Off. Orhuwhorun Rd & 2.86 & 14.14 \\
\hline 5.795667 & 5.501306 & 3, Visa Link Rd. Off. Orhuwhorun Rd & 2.3 & 9.7 \\
\hline 5.782778 & 5.493056 & Noriel Tueje Compound, Off Ovwian Mrk & 3.5 & 9.5 \\
\hline 5.748722 & 5.474083 & Gbobome Comp. Gramm. Sch. Rd. Aladja & 1.7 & 15.3 \\
\hline 5.757917 & 5.490444 & Tom Compound Off Obierurhu St. Aladja & 1.5 & 19.5 \\
\hline 5.757222 & 5.480417 & Calvary Baptist Church Aladja & 2.6 & 12.4 \\
\hline 5.818028 & 5.495 & 14, White House Lagos Rd DSC & 2.1 & 7.9 \\
\hline 5.836306 & 5.508056 & Ekreku Comp. by Usieffrun Junction Orhuwhorun & 3.6 & 9.4 \\
\hline 5.826472 & 5.509083 & Esyai Close Opp. Itaigho F/S Orhuwhorun & 3.3 & 6.7 \\
\hline 5.789083 & 5.563444 & 3, Onaya St. Off Ovie Palace Rd. Effurun & 1.6 & 18.4 \\
\hline 5.769667 & 5.568861 & 1, Osademe St. (Km2) Off Refinery Rd. & 1.6 & 14.4 \\
\hline 5.768083 & 5.577583 & Army Barrack (Block 23) & 2.1 & 5.9 \\
\hline 5.763 & 5.566306 & 10, Indian Close Off Jakpa Road & 2.8 & 11.2 \\
\hline 5.780389 & 5.55525 & 9, Okito St.Off Jakpa Rd. Sokoh Estate & 2.65 & 4.35 \\
\hline 5.782528 & 5.549111 & BH Conoil, Airport Junction, Effurun & 5 & 15 \\
\hline 5.779028 & 5.545528 & Our Ladys High School Effurun & 3.8 & 18.2 \\
\hline 5.787639 & 5.555139 & Arubaye Comp. by Shrine Effurun Market & 3.17 & 18.83 \\
\hline 5.7615 & 5.527333 & 1, Willy St. Off Deco Road. & 1 & 9 \\
\hline 5.758889 & 5.520778 & 24, Bazunu Rd. Opp. Akajuigo Plaza Igbudu & 2.43 & 10.57 \\
\hline 5.753722 & 5.514022 & 11G, Bazunu Comp. Otowodo Agbassa & 1.9 & 14.1 \\
\hline 5.744472 & 5.512156 & 3, House Rd Main Mkt, Ogbe Joh & 3.2 & 9.8 \\
\hline 5.762917 & 5.514889 & 1, Edesoh St. Off Essi Layout & 2.55 & 10.45 \\
\hline 5.768972 & 5.526194 & 14, Ajuyahs St Marine Quarters & 2.7 & 14.3 \\
\hline 5.778917 & 5.535139 & Urhobo College, Effurun & 2.1 & 8.9 \\
\hline 5.7665 & 5.544806 & Opp. Jnr Staff Club Bendel Estate. & 1.95 & 9.1 \\
\hline 5.750417 & 5.541889 & 3, Akpala St. B/H Holy Family Sch. Ugboroke & 0.75 & 19.25 \\
\hline 5.734556 & 5.526528 & 2, Arimo Close, Off Olu Palace & 2.1 & 9.9 \\
\hline 5.73125 & 5.523139 & Ogiame Primary School Ekurede Itsekiri & 1.8 & 8.2 \\
\hline 5.712222 & 5.531472 & City Ovwuvwe Comp. Ogunu Village & 2.7 & 5.3 \\
\hline 5.742472 & 5.525972 & 31B, Ekpen St Okere Warri & 3.1 & 9.9 \\
\hline 5.750944 & 5.530889 & 10, Ohwadjeke St Okumagba Layout. & 1.4 & 23.6 \\
\hline 5.756417 & 5.535111 & 11, Grey St Off Poloko Okumagba Layout & 2.25 & 17.75 \\
\hline 5.762194 & 5.537194 & 42, Ohwonigho Comp Ugborikoko & 1.53 & 12.47 \\
\hline 5.803028 & 5.566583 & Ezekiel Close, Jefia Ave. Off P.T.I Rd & 0.77 & 12.23 \\
\hline 5.734139 & 5.517861 & Central Hospital Warri & 1.4 & 17.6 \\
\hline
\end{tabular}

\subsection{Occurrence and Distribution of Lead and Cadmium in Groundwater}

Lead was detected in more than eighty per cent of all samples collected and ranged in concentration from $0-0.04 \mathrm{mg} / 1$. The highest value for lead was obtained from a well near the Ubeji Health Center that returned a value of $0.04 \mathrm{mg} / \mathrm{l}$ followed by the sample from a dug well at the Ogiame Primary School, Ekurede -Itsekiri area. 
Spatial details of the occurrence of lead are presented in Table 2 which consists of data from randomly selected locations and which data has been used in constructing the iso-concentration map shown in Figure 3 . The occurrence of groundwater impaired by the presence of lead above the WHO Drinking water guideline value of $0.01 \mathrm{mg} / \mathrm{l}$ is not limited to these two locations but as suggested by the isocons in Figure 3 spreads to the Ekurede Urhobo, the Warri GRA, NPA and Ogunu neighborhoods. At Ubeji, Figure 3 also suggests the presence of a source of lead contamination around or near the Health Center from which the contamination is spreading westwards.

Cadmium ranged from $0-0.040 \mathrm{mg} / \mathrm{l}$ and the highest value was obtained from a well at the Okere neighborhood. Cadmium is predominantly above the WHO limit of $0.003 \mathrm{mg} / 1$ everywhere in the city except in the isolated areas of Ekete and Ovwian to the east. Iso - concentration contours for cadmium, Figure 4 constructed from data in Table 2 show that the highest concentrations of cadmium in groundwater are in the older and more densely populated neighborhoods of Ekurede Itsekiri, Warri GRA, Ekurede Urhobo, Okere, Edjeba and Agbassa.

Table 2. Levels of occurrence of lead and cadmium at different parts of Effurun-Warri

\begin{tabular}{lllll}
\hline Easting & Northing & Location Name & Cadmium(mg/l) & Lead(mg/l) \\
\hline 5.704667 & 5.57105 & Ubeji Health Centre & 0.008 & 0.04 \\
5.707861 & 5.570611 & Town Hall Ubeji & 0.003 & 0.002 \\
5.692333 & 5.571472 & Seko Est Ubeji Deeper Life Road, Ubeji & 0.005 & 0.001 \\
5.722167 & 5.573056 & Jeddo/Ubeji Junction & 0.007 & 0.003 \\
5.826889 & 5.579694 & 1, James Ovie St. Okuokoko & 0.006 & 0.001 \\
5.789917 & 5.506889 & 17, Boro St. Owhasa Off. Orhuwhorun Rd & 0.001 & 0.001 \\
5.795667 & 5.501306 & 3, Visa Link Rd. Off. Orhuwhorun Rd & 0.002 & 0.002 \\
5.782778 & 5.493056 & Noriel Tueje Compound, Off Ovwian Mrk. & 0 & 0 \\
5.757222 & 5.480417 & Calvary Baptist Church Aladja & 0.005 & 0.001 \\
5.818028 & 5.495 & 14, White House Lagos Rd DSC & 0.006 & 0.004 \\
5.789083 & 5.563444 & 3, Onaya St. Off Ovie Palace Rd. Effurun & 0.005 & 0.003 \\
5.768083 & 5.577583 & Army Barrack (Block 23) & ND & ND \\
5.778917 & 5.535139 & Urhobo College, Effurun & 0.009 & 0.001 \\
5.73125 & 5.523139 & Ogiame Primary School Ekurede Itsekiri & 0.04 & 0.006 \\
5.742472 & 5.525972 & 31B, Ekpen St Okere Warri & 0.003 & 0.019 \\
5.750417 & 5.541889 & 3, Akpala St. B/H Holy Family Sch. Ugboroke & 0.009 & 0.001 \\
5.748722 & 5.474083 & Gbobome Comp. Gramm. Sch. Rd. Aladja & ND & ND \\
\hline
\end{tabular}

Note: $\mathrm{ND}=$ Not detected. 


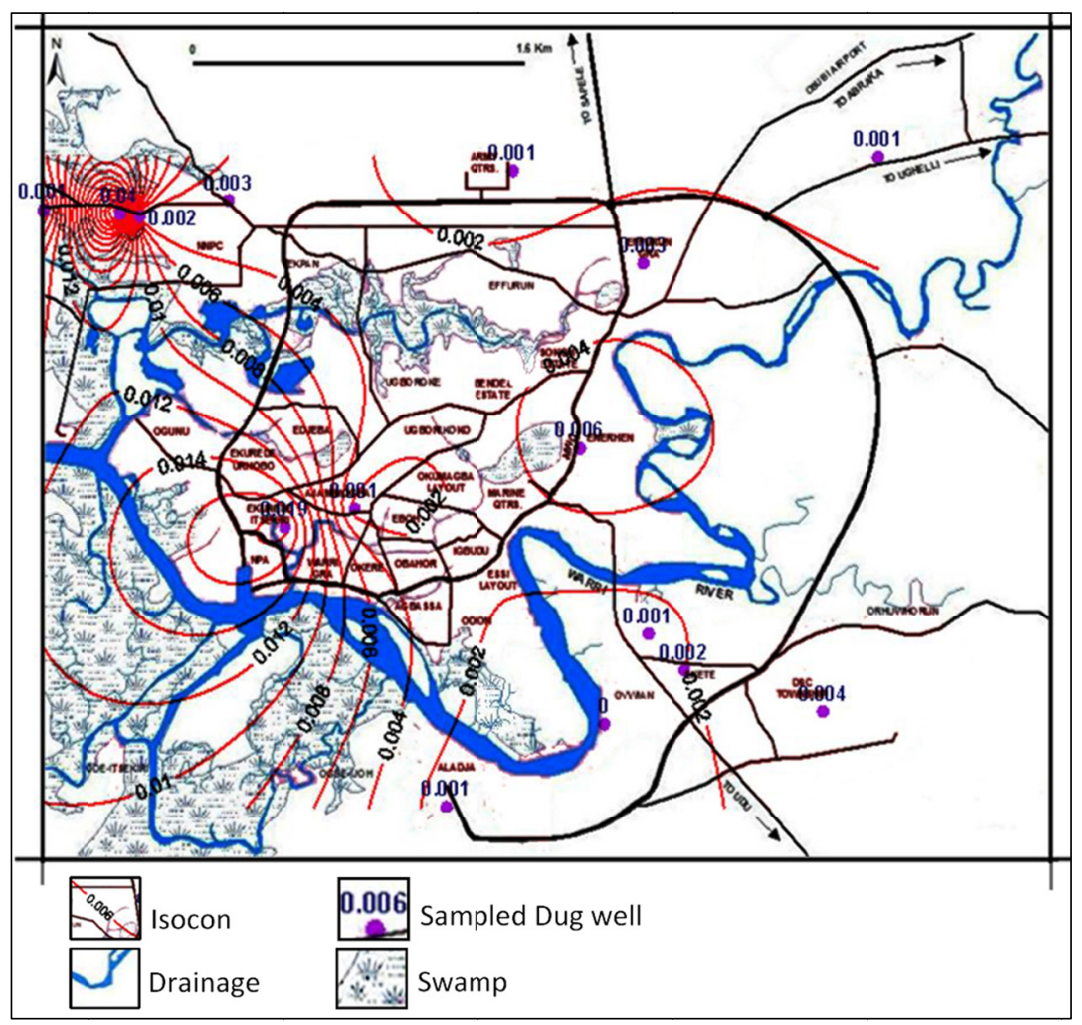

Figure 3. Lead isocons in Effurun -Warri metropolis (Base map modified from Urhobo Historical Society, 2014)

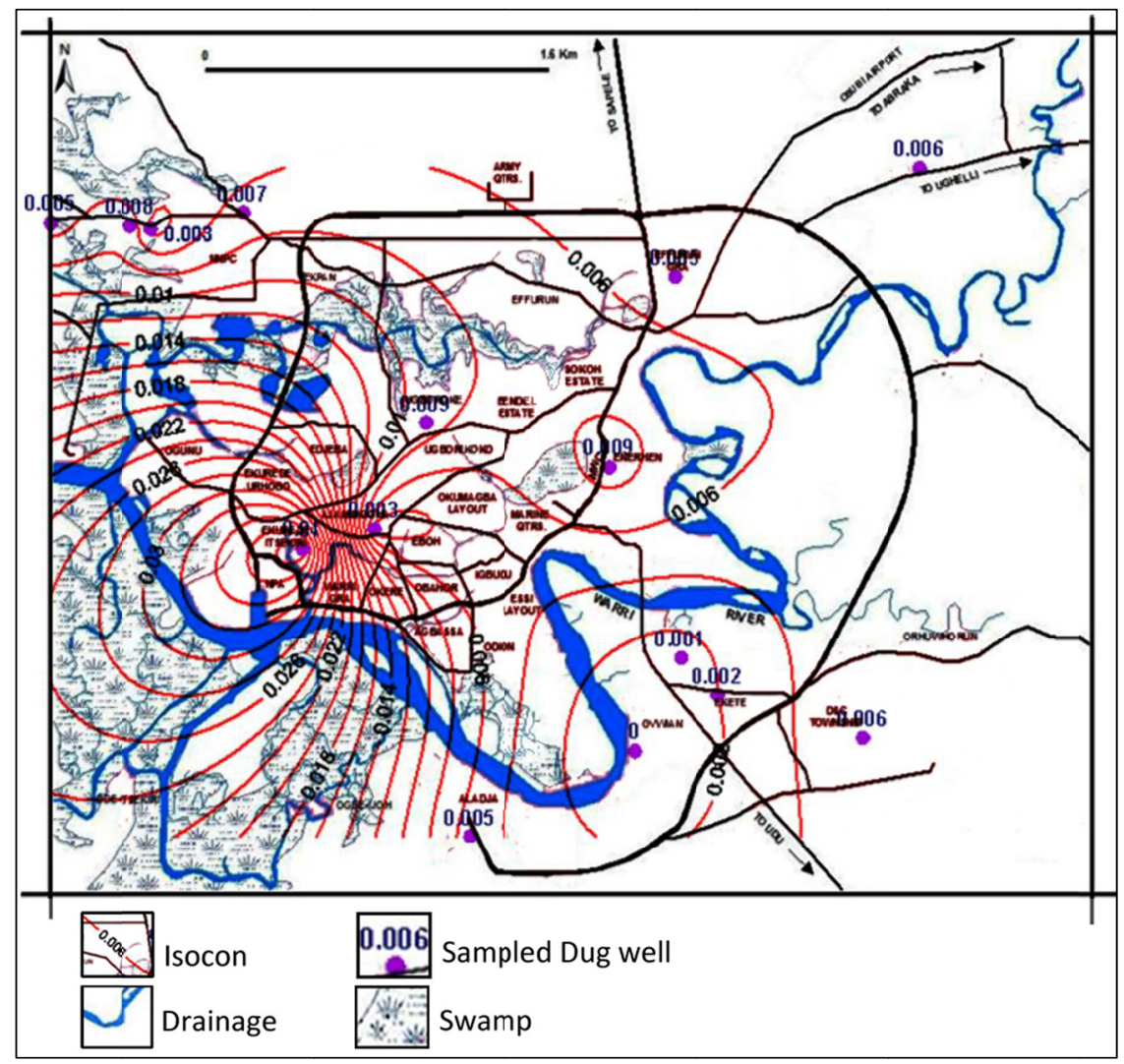

Figure 4. Cadmium isocons in Effurun- Warri metropolis

(Base map modified from Urhobo Historical Society, 2014) 


\section{Discussion}

\subsection{Urbanization, Waste Management and Spatial Distribution of Lead and Cadmium}

The distribution of lead and cadmium in groundwater as may be observed from Figure 3and Figure 4 indicate that the western half of the city appears to be more susceptible to heavy metal contamination than the east. A possible explanation for this could be that the western half constitutes the more densely populated older neighborhoods around which other previously rural communities have agglomerated in the past 50 years to form the current metropolis. Westward city expansion has been limited by the BMS on the city's western edge. The NNPC refinery and petrochemical complex located on the northwest corner have also influenced city expansion in that area such that the previously rustic Ubeji community located there has experienced rapid development in the last decade. The implication of this for spatial distribution of contaminants in groundwater relates to the historical location of commerce and industry as well as well as waste disposal sites in the city. Dumpsites and associated leachate in the city have been implicated in the generation of heavy metals and their elevated levels of occurrence in ground water (Adebisi et al., 2013; Iwegbue et al., 2010; Ogbeibu et al., 2013; Akudo et al., 2010; Otobo et al., 2007). These studies all show that leachate from dumpsites is laden with lead and cadmium among others at varying degrees of magnitude. Furthermore, twenty one out of the twenty five large, open and unregulated garbage dump sites identified in a city wide study by Efe, Akosua and Ojoh (2013) are located in the core more densely populated older neighbourhoods of the western section and these dumpsites accounted for approximately 80 per cent of all waste generated in the city. Moreover, many former dumpsites in these older neighbourhoods where land for construction purposes is at a premium have been reclaimed and built up and there is now no evidence of their former existence. However, they would probably continue to possess the potential for pollution depending on the manner and process of reclamation as well as the age of such former dumpsites (Adebisi et al., 2013). Such reclaimed dumpsites essentially fall into the category of sources of heavy metal contamination described as legacy sites by the World Health Organization (WHO, 2010).

When viewed together, Figure 2, Figure 3and Figure 4 suggest that the nature of existing groundwater gradients is a likely explanation for the confinement of the highest levels of lead and cadmium to the western sector of the city. It is also responsible for the noticeable presence of lead in groundwater at Ubeji and other communities that are north, west and southwest of the NNPC refinery and petrochemical complex whose waste streams have been identified by Ethcie et al. (2011) and Nduka and Orisakwe (2011) as the source of heavy metal loading to both surface water and groundwater in that area. Ground water to the east of the complex is as a result remarkably and relatively lower in lead content when compared with water from the western sector. This is because ground water movement as shown in Figure 2 is consistently westwards or southwards from the refinery and petrochemical complex area and contaminants from them would move in these directions and would be prevented from moving eastwards by the existing south and northwestward gradient.

Cadmium contamination on the other hand is more widespread and evenly distributed over the city perhaps because it is also associated with soils (Iwegbue et al., 2010) and leachates from existing garbage dumpsites. Furthermore, road side soils, sediment in open drains and storm water runoff have been implicated as continuous sources of cadmium and lead enrichment to ground water by Egboh, Nwajei and Adaikpoh (2000). The groundwater flow regime indicated in Figure 2 ensures hydrogeochemical mixing and the resultant widespread occurrence of cadmium. It therefore appears that the existence of contaminants from point sources has been long term and their spread has over time been governed by existing groundwater gradients and flow directions.

\subsection{Potential Implications for Public Health and Regional Water Quality Monitoring}

The widespread occurrence of lead and cadmium in groundwater is not peculiar to the Warri-Effurun area, but has also been observed in other parts of the western Niger Delta region. West of Warri at Ughoton and Omadino for example, mean lead $(0.019 \mathrm{mg} / \mathrm{l})$ and cadmium $(0.02 \mathrm{mg} / \mathrm{l})$ in groundwater from dug wells has been reported by Akpoborie and Aweto (2012). Eriyamremu et al. (2005) have also associated the presence of elevated levels of lead and cadmium in vegetables grown in parts of the Warri area and further west at Forcados to urbanization and industrial pollution.

Furthermore, the linkage between access to clean and acceptable quality water and maternal health in Nigeria has been stressed by Ezenwaji and Otti (2013) who suggest that lack of access is a major factor that contributes to the current high rate of maternal mortality. Indeed, Uriri, Babatola and Akintuyi (2011) and Babatola and Uriri (2013) also forcefully suggest a strong association between poor quality water usage and the abnormally high maternal mortality rates and other negative reproductive health indices they recorded from the Effurun-Warri metropolis. The widespread distribution of lead and cadmium in the city's shallow dug well water, lends support to this argument. 
Unfortunately, the expense and equipment requirements for screening for heavy metals preclude their inclusion in the list of parameters that are evaluated by the public water supply agencies in routine water quality certification and monitoring programs (Akpoborie, Ebenuwa \& Emonyan, 2011). Thus the possibility exists that groundwater with dangerous heavy mineral content could be and is potentially and routinely being certified by public agencies as fit for drinking and other domestic purposes. Indeed, local and regional water quality surveys that are undertaken in Nigeria (Olobaniyi, Ogban, Ejechi, \& Ugbe, 2007; Ince et al., 2010; Edet, Nganje, Ukpong, \& Ekwere, 2011) have also ignored the presence of heavy metals in groundwater. This is further compounded by the fact that the regulatory limits for lead and cadmium in drinking water provided by the Standard Organization of Nigeria are contradictory: NIS 554:2007 the Nigerian Standard for Drinking Water Quality specifies a Maximum Permissible Limit (MPL) of $0.003 \mathrm{mg} / \mathrm{l}$ for Cadmium and $0.01 \mathrm{mg} / 1$ for lead while NIS 345:2008 the Standard for Mineral Waters that guides the production of packaged water specifies MPLs of $0.01 \mathrm{mg} / \mathrm{l}$ and $0.05 \mathrm{mg} / 1$ for cadmium and lead respectively (SON, 2007; 2008). This inconsistency is indeed the reason the WHO (2006) standard was used as the standard for comparison and discussion in this study.

\section{Conclusion}

A ground water head distribution map of the shallow Benin Formation aquifer in the Effurun-Warri area has been presented and used to identify directions of groundwater movement in the metropolis. The spatial distribution of lead suggest that lead in groundwater exceeds the WHO maximum allowable limits in a large part of the city and that lead enrichment may be from two source areas: the NNPC refinery and petrochemical wastes in the northwestern part of the city and from leachates associated with unregulated dumpsites that have been traditionally used for waste disposal in the city. Existing ground water gradients may be responsible for the confinement of elevated levels of lead in groundwater to the city's western sector. Elevated levels of cadmium in groundwater above WHO maximum allowable limits in drinking water are more widespread and evenly distributed in the area, again because of the prevalent long term use of open and unregulated dumpsites as well as the possible mixing of ground water as suggested by existing gradients. The toxicity of these heavy metals requires that their presence in groundwater be constantly monitored.

\section{Acknowledgement}

This investigation was undertaken with the aid of partial funding and resources provided by the Center for Research in Water and Environment (CREWE), Abraka and for which the authors are grateful.

\section{References}

Abimbola, A. F., Oke, S. A., \& Olatunji, A. S. (2002). Environmental Impact assessment of waste Dump sites on geochemical quality of water and soils in Warri metropolis, southern Nigeria. Water Resources, 13, 7-11.

Adebisi, N. O., Oluwafemi, O. S., Songca, S. P., \& Haruna, I. (2013). Flow system, physical properties and heavy metals concentration of groundwater: A case study of an area within a municipal landfill site. International Journal of Water Resources and Environmental Engineering, 5(11), 630-638. http://dx.doi.org/10.5897/IJWREE2013.0427

Adejuwon, O. A. (2012). Rainfall Seasonality in the Niger Delta Belt, Nigeria. Journal of Geography and Regional Planning, 5(2), 51-60. http://dx.doi.org/10.5897/JGRP11.096

Adewosu, H. O., Adewuyi, G. O., \& Adie, G. G. (2013). Assessment of Heavy Metals in Soil, Leachate and underground water samples collected from the vicinity of Olusosun landfill in Ojota, Lagos, Nigeria. Transnational Journal of Science and Technology, 3(6), 73-86.

Akoteyon, I. S., Mbata, U. A., \& Olalude, G. A. (2011). Investigation of heavy metal contamination in groundwater around landfill site in a typical sub-urban settlement in Alimosho, Lagos-Nigeria. Journal of Applied Sciences in Environmental Sanitation, 6(2), 155-163.

Akpoborie, I. A., \& Aweto, K. E. (2012). Ground water conditions in the Mangrove Swamps of the Western Niger Delta: Case study of the Ughoton Area, Delta state, Nigeria. Jour. Env. Hydrology, 20, 1-14.

Akpoborie, I. A., Ekakite, O. A., \& Adaikpoh, E. O. (2000). The Quality of Groundwater from Dug Wells in Parts of the Western Niger Delta. Knowledge Review, 2(5), 72-75.

Akpoborie, I. A., Ebenuwa, C. C., \& Emonyan, O. O. (2009). Water Quality Monitoring in Delta State, Nigeria: Status, Rights to Water and the Millennium Development Goals. Presented at the $2^{\text {nd }}$ Annual Faculty of Social Science International Conference, Delta State University, Abraka, December 10-12. 
Akudo, E. O., Ozulu, G. U., \& Osogbue, L. C. (2010). Quality Assessment of groundwater in selected waste dump site areas in Warri. Environmental Research Journal, 4(4), 281-285. http://dx.doi.org/10.3923/erj.2010.281.285

Allen, J. R. L. (1965). Late Quaternary Niger Delta and Adjacent Areas: Sedimentary Environments and Lithofacies. Bulletin American Association of Petroleum Geologists, 49(5), 547-600.

AMCOG. (2012). Committee Opinion No. 533: Lead screening during pregnancy and lactation. Obtet Gynecol, $120,416-20$.

Aremu, D. A., Olawuyi, J. F., Metshitsuka, S., Sridhar, M. K., \& Oluwande, P. A. (2002). Heavy metal analysis of groundwater from Warri, Nigeria. International Journal of Environmental Health Research, 12(3), 261-267. http://dx.doi.org/10.1080/0960312021000001014

Asiwaju-Bello, A. Y. (2007). Contaminant plume migration patterns in ground water around Oke-Odo refuse dump site, Lagos, Nigeria. Water Resources, 17, 24-28.

Agency for Toxic Substances and Disease Registry. (2007). Toxicological Profile for Lead. ATSDR, Atlanta, Ga., USA.

Babatola, O., \& Uriri, A. (2013). Assessment of Maternal Health Intervention Programme of Delta State, Nigeria: Application of the U.N Process Indicators. Journal of Public Policy and Administration Research, 3(9), 62-71.

Basorun, J. O., \& Olamiju, I. O. (2013). Environmental Pollution and Refinery Operations in an Oil Producing Region of Nigeria: A Focus on Warri Petrochemical Company. Journal of Environmental Science, Toxicology and Food Technology, 2(6), 18-23.

Edet, A., Nganje, T. N., Ukpong, A. J., \& Ekwere, A. S. (2011). Groundwater chemistry and quality of Nigeria: A status review. African Journal of Environmental Science and Technology, 5(13), 1152-1169. http://dx.doi.org/ 10.5897/AJESTX11.011

Efe, S. I. (2005). Urban effects on precipitation amount and rainwater quality in Warri metropolis (Ph.D. Thesis). Delta State University, Abraka.

Efe, S. I., Cheke, L. A., \& Ojoh, C. O. (2013). Effects of Solid Waste on Urban Warming in Warri Metropolis, Nigeria. Atmospheric and Climate Sciences, 3, 6-12. http://dx.doi.org/10.4236/acs.2013.34A002

Egboh, S. H. O., Nwajei, G. E., \& Adaikpoh, E. O. (2000). Selected Heavy metals concentration in sediments from major roads and gutters in Warri, Delta State, Nigeria. Nig. J. Sc. Env., 2, 105-111.

Ejechi, B. O., Olobaniyi, S. B., Ogban, F. E., \& Ugbe, F. C. (2007). Physical and Sanitary Quality of Hand Dug Well Water from Oil producing area of Nigeria. Environ Monit Assess., 128, 495-501. http://dx.doi.org/10.1007/s10661-006-9343-1

Emoyan, O. O., Akporhonor, E. E., \& Akpoborie, I. A. (2008). Environmental Risk Assessment of River Ijana, Ekpan, Delta State. Chem. Spec. and Bioavailability, 20(1), 23-32. http://dx.doi.org/10.3184/095422908X295825

Eriyamvemu, G. E., Asagba, S. O., Akpoborie, I. A., \& Ojeaburu, S. I. (2005). Evaluation of Lead and Cadmium Levels in Some Commonly Consumed Vegetables in the Niger Delta Oil Area of Nigeria. Bull. Env. Contam. Toxicol., 75, 278-283. http://dx.doi.org/10.1007/s00128-005-0749-1

Etchie, T. O., Etchie, A. T., \& Adewuyi, G. O. (2011). Source Identification of Chemical Contaminants in Environmental Media of a Rural Settlement. Research Journal of Environmental Sciences, 5, 730-740. http://dx.doi.org/10.3923/rjes.2011.730.740

Ezenwaji, E. E., \& Otti, V. I. (2013). Water Related Diseases as a Challenge to the Implementation of Reproductive Health of Pregnant Women in Anambra State, Nigeria. International Journal of Engineering and Technology, 3, 2049-3444.

Golden Software Inc. (2002). Surfer 8. Golden Software Inc. Co. USA

Ifegwu, C., \& Anyakora, C. (2012). Screen for Eight Heavy Metals from Groundwater Samples from a Highly Industrialized Area in Lagos, Nigeria. African Journal of Pharmaceutical Sciences and Pharmacy, 3(1), 1-16. 
Ince, M., Bashir, D., Oni, O. O. O., Awe, E. O., Ogbechie, V., Korve, K., ... Kehinde, M. (2010). Rapid assessment of drinking water quality in the federal Republic of Nigeria Country Report of the Pilot Project implementation 2004-2005. WHO-Unicef.

Iwegbue, C. M., Nwajei, G. E., Ogala, J. E., \& Overah, C. L. (2010). Determination of trace metal concentrations in soil profiles of municipal waste dumps in Nigeria. Environ Geochem Health, 32, 415-430 http://dx.doi.org/10.1007/s10653-010-9285-y

Nduka, J. K., \& Orisakwe, O. E. (2007). Heavy Metal Levels and Physico - Chemical Quality of Potable Water Supply in Warri, Nigeria. Annali di Chimica, 97, 867-874. http://dx.doi.org/10.1002/adic.200790071

Nduka, J. K., \& Orisakwe, O. E. (2009). Effect of Effluents from Warri Refinery Petrochemical Company WRPC on Water and Soil Qualities of "Contiguous Host" and "Impacted on Communities" of Delta State, Nigeria. The Open Environmental Pollution \& Toxicology Journal, 1, 11-17. http://dx.doi.org/10.2174/1876397900901010011

Ogbeibu, A. E., Chukwurah, A. E., \& Oboh, I. P. (2013). Effects of Open Waste Dump-site on its Surrounding Surface Water Quality in Ekurede-urhobo, Warri, Delta State, Nigeria. Natural Environment, 1(1), 1-16. http://dx.doi.org/ 10.12966/ne.06.01.2013

Olobaniyi, S. B., \& Owoyemi, F. B. (2004). Quality of Groundwater in Deltaic Plain Sands Aquifer of Warri and Environs, Delta State, Nigeria. Water Resources, 15, 38-45.

Olobaniyi, S. B., Ogban, F. E., Ejechi, B. O., \& Ugbe, F. C. (2007). Quality of groundwater in Delta State, Nigeria. Jour. Env. Hydrology, 15, 1-11.

Otobo, E., Aigbogun, C. O., \& Ifedili, S. O. (2007). Geoelectrical Evaluation of Waste Dump Sites at Warri and its Environ, Delta State, Nigeria. J. Appl. Sci. Environ. Manage, 11(2), 61-64.

Sarojam, P. (2011). Analysis of $\mathrm{Pb}, \mathrm{Cd}$ and As in Tea Leaves Using Graphite Furnace Atomic Absorption Spectrophotometry, Application Note, PerkinElmer, Inc., USA. Retrieved from http://www.perkinelmer.com/CMSResources/Images/APP_Metals_In_Tea_Leaves_PinAAcle_GFAA.pdf

Short, K. C., \& Stauble, A. J. (1967). Outline of geology of Niger delta. Bull. Amer. Assoc. Petr. Geol., 54(5), 761-779.

Standards Organization of Nigeria. (2007). Nigerian Standard for Drinking Water Quality (p. 30). NIS 554:2007. Abuja.

Standards Organization of Nigeria. (2008). Standard for Natural Mineral Waters (p. 10). NIS 345:2008, Abuja.

Urhobo Historical Society. (2014). A map of Effurun-Warri Area, 1986. Retrieved from www.waado.org/warri/maps/effurun_warri_1986.html

Uriri, A., Babatola, O., \& Akintuyi, A. (2011). Patterns of Antenatal, Postnatal \& Maternal Deaths in Delta State, Nigeria: A Spatio-Temporal Analysis: 2007-2010. University of Lagos 7th Annual Research Conference \& Fair: 19th -21st, October.

World Health Organization. (2006). Guidelines and Standards for Drinking Water (3rd ed). WHO, Geneva.

WHO. (2011). Cadmium in Drinking-water Background document for development of WHO Guidelines for Drinking-water Quality WHO/SDE/WSH/03.04/80/Rev/1

WHO. (2010). Childhood Lead Poisoning. WHO, Geneva, Switzerland.

\section{Copyrights}

Copyright for this article is retained by the author(s), with first publication rights granted to the journal.

This is an open-access article distributed under the terms and conditions of the Creative Commons Attribution license (http://creativecommons.org/licenses/by/3.0/). 